ORIGINAL ARTICLE

\title{
SAND FLY SPECIES COMPOSITION (DIPTERA: PSYCHODIDAE: PHLEBOTOMINAE) IN THE MUNICIPALITY OF CANTAGALO, AN AREA WITH SPORADIC CASES OF HUMAN CUTANEOUS LEISHMANIASIS IN RIO DE JANEIRO STATE, BRAZIL
}

Quezia Nunes PERES-DIAS(1), Claudete Diniz OLIVEIRA(2), Marcos Barbosa de SOUZA(1), Antônio de Medeiros MEIRA(1) \& Ciro Benigno VILLANOVA(1)

\begin{abstract}
SUMMARY
The municipality of Cantagalo is an area with sustained transmission of American Cutaneous Leishmaniasis (ACL). Monthly sand fly collections were performed for three years (June 2012 - May 2015) using a CDC light trap. A total of 3,310 specimens belonging to 12 species were trapped: Nyssomyia intermedia, Nyssomyia whitmani, Migonemyia migonei, Evandromyia lenti, Evandromyia cortelezzii, Micropygomyia quinquefer, Brumptomyia brumpti, Psathyromyia aragaoi, Micropygomyia schreiberi, Pintomyia fischeri, Sciopemyia sordellii, and Evandromyia edwardsi. The last seven species have not been previously recorded in this area. The highest abundance of species occurred between October and March. October was the month with the highest number of captured sand flies, one month before the peak in the summer rainfall. In October the highest number of $\mathrm{Ny}$. intermedia, $\mathrm{Ny}$. whitmani and $\mathrm{Mg}$. migonei, were also collected, the three epidemiologically most important species. The high abundance of species with epidemiological importance for ACL transmission might explain the sporadic occurrence of the disease in the area.
\end{abstract}

KEYWORDS: American Cutaneous Leishmaniasis; Sand flies; Vectors.

\section{INTRODUCTION}

Since 2003, American Cutaneous Leishmaniasis (ACL) has been reported in all Brazilian States. More recently, 61 (66\%) of 92 municipalities in Rio de Janeiro State reported increasing ACL cases between 2007 and $2013^{1}$ (Fig. 1-A).

The municipality of Cantagalo is an area where eight autochthonous cases of ACL were reported between 2005 and 2006. Since 2007, four autochthonous cases of ACL were reported: one case in 2007, two cases in 2008, and one case in 2012 ${ }^{1}$. Cantagalo ranked $21^{\text {st }}$ among the municipalities of Rio de Janeiro State, however has had the highest number of ACL cases during this period. Nevertheless, little is known about ACL sand fly vectors in this area of Rio de Janeiro State.

Here we present the results of three years of entomological survey in the municipality of Cantagalo, Rio de Janeiro, Brazil. Our goal was to describe the sand fly fauna and to identify dominant vector species in this area of sustained ACL transmission.

\section{MATERIAL AND METHODS}

\section{Study area}

Cantagalo ( $\left.21^{\circ} 58^{\prime} 52^{\prime \prime} \mathrm{S} 42^{\circ} 22^{\prime} 05^{\prime \prime} \mathrm{W}\right)$ is located in the mountain region of Rio de Janeiro State, $200 \mathrm{~km}$ from the state capital, bordering Minas Gerais State.

This municipality had an estimated population of 19,792 inhabitants in 2014; it has an area of $749.279 \mathrm{~km}^{2}$, an altitude of $391 \mathrm{~m}$, a tropical climate with temperatures ranging between $19{ }^{\circ} \mathrm{C}$ and $26^{\circ} \mathrm{C}$ and two well defined seasons: a typically rainy summer concentrating over $80 \%$ of the rainfall and a predominantly dry winter. The area has scattered fragments of the Atlantic Forest ${ }^{2}$.

\section{Entomological captures}

Collections were made using a single Centers for Disease Control (CDC) light trap one day per month, alternately on both sites (districts): Euclidelândia and Boa Sorte (Fig. 1-B). The sampling was performed monthly from June 2012 to May 2015, totaling 36 months of collection. The light trap was set in peridomiciliary areas (one meter above the floor) from $7 \mathrm{pm}$ to $7 \mathrm{am}$, totaling $12 \mathrm{~h}$ of collection per day.

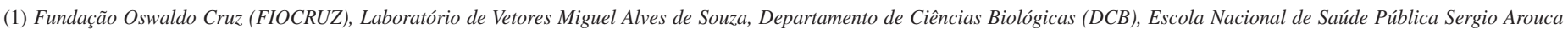
(ENSP). Rio de Janeiro, RJ, Brazil. 


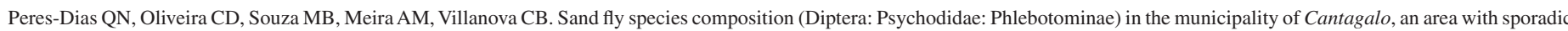
cases of human cutaneous leishmaniasis in Rio de Janeiro State, Brazil. Rev Inst Med Trop Sao Paulo. 2016;58:50.
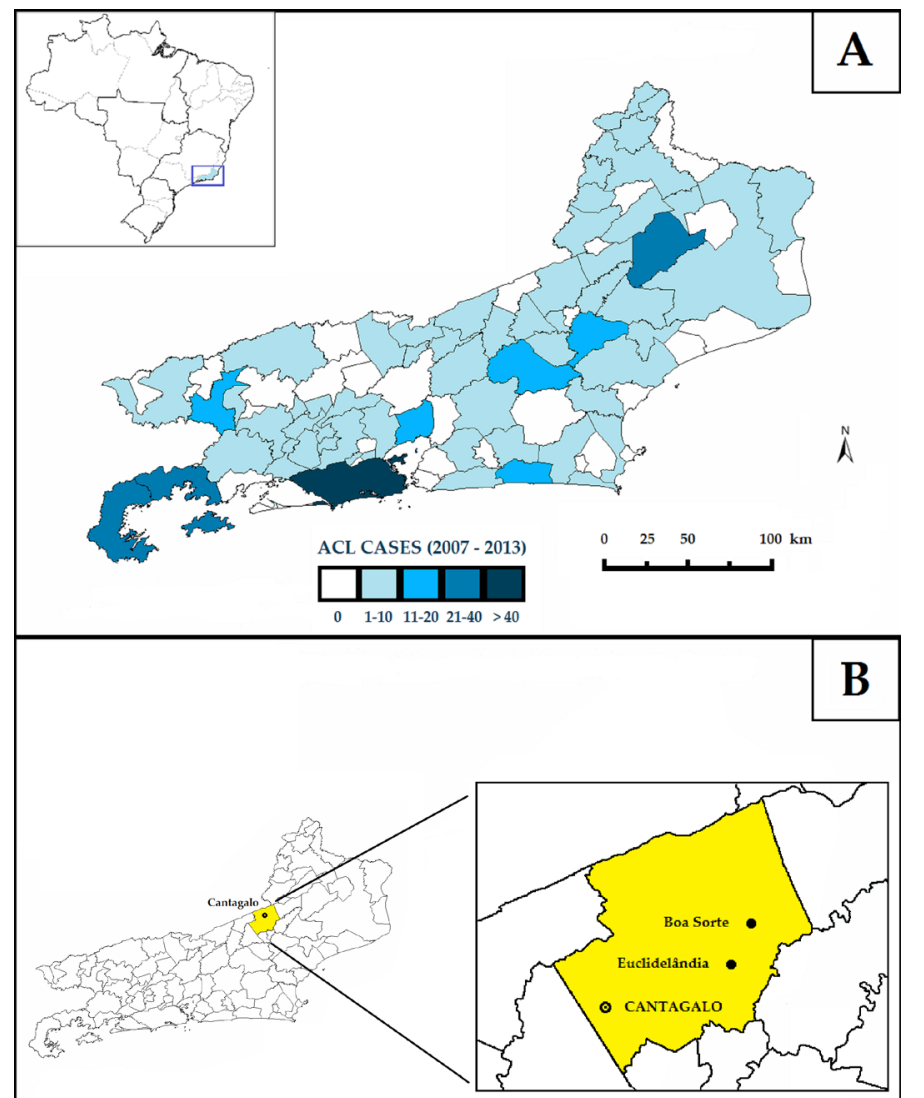

Fig 1 - Number of cases of ACL reported in the municipalities of Rio de Janeiro State from 2007 to 2013 (last year with infection records available)
The collected specimens were placed in plastic tubes containing $70 \%$ alcohol cleared in $10 \%$ potassium hydroxide solution $(\mathrm{KOH})$ for 2 $\mathrm{h}$, and then identified based on morphological characteristics, mainly the morphology of spermathecae and cibarium (females), as well as male terminalia, according to the nomenclature proposed by Galati $(2003)^{3}$.

\section{RESULTS}

A total of 3,310 specimens belonging to 12 species were captured (Table 1): Nyssomyia intermedia, Nyssomyia whitmani, Migonemyia migonei, Evandromyia lenti, Evandromyia cortelezzii, Micropygomyia quinquefer, Brumptomyia brumpti, Psathyromyia aragaoi, Micropygomyia schreiberi, Pintomyia fischeri, Sciopemyia sordellii, and Evandromyia edwardsi.

\section{DISCUSSION}

Carvalho et al. (2014) $)^{4}$ published a review on the sand fly fauna of Rio de Janeiro State with data from 2002 to 2012, in which the presence of only six species of sand flies was reported in the municipality of Cantagalo. In our study, a total of twelve species were identified, seven of which have been detected for the first time in this municipality: Evandromyia cortelezzii, Evandromyia lenti, Brumptomyia brumpti, Psathyromyia aragaoi, Micropygomyia schreiberi, Sciopemyia sordellii, and Evandromyia edwardsi. This fact might reflect that our sampling was more comprehensive ${ }^{5}$, that sampling with CDC traps allowed the capture of additional species ${ }^{6}$, opening questions about which other species could have been found if we had also used sampling techniques aimed at resting sand flies ${ }^{7}$, or whether the new species are actually invading the studied area.

The five most abundant species collected in the region were $N y$. intermedia (38\%), followed by Ny. whitmani (24\%), Ev. lenti (19\%), Ev. cortelezzii (8\%), and Mg. migonei (7\%).

Table 1

Sand fly species captured from 2012 to May 2015 in the municipality of Cantagalo, Rio de Janeiro State

\begin{tabular}{|c|c|c|c|c|c|c|}
\hline \multirow{2}{*}{ Species } & \multicolumn{2}{|c|}{ Females } & \multicolumn{2}{|c|}{ Males } & \multicolumn{2}{|c|}{ Total } \\
\hline & $n^{\circ}$ & $\%$ & $n^{\circ}$ & $\%$ & $n^{\circ}$ & $\%$ \\
\hline Ny. intermedia & 620 & 43.75 & 660 & 34.87 & 1280 & 38.67 \\
\hline Ny. whitmani & 367 & 25.90 & 442 & 23.35 & 809 & 24.44 \\
\hline Ev. lenti & 174 & 12.28 & 457 & 24.14 & 631 & 19.06 \\
\hline Ev. cortelezzii & 162 & 11.43 & 107 & 5.65 & 269 & 8.13 \\
\hline Mg. migonei & 58 & 4.09 & 181 & 9.56 & 239 & 7.22 \\
\hline Mi. quinquefer & 5 & 0.35 & 21 & 1.11 & 26 & 0.79 \\
\hline Br. brumpti & 5 & 0.35 & 20 & 1.06 & 25 & 0.76 \\
\hline Pa. aragaoi & 11 & 0.78 & 1 & 0.05 & 12 & 0.36 \\
\hline Mi. schreiberi & 8 & 0.56 & 3 & 0.16 & 11 & 0.33 \\
\hline Pi. fischeri & 5 & 0.35 & 0 & 0.00 & 5 & 0.15 \\
\hline Sc. sordellii & 2 & 0.14 & 0 & 0.00 & 2 & 0.06 \\
\hline Ev. edwardsi & 0 & 0.00 & 1 & 0.05 & 1 & 0.03 \\
\hline Total & 1,417 & 100.00 & 1,893 & 100.00 & 3,310 & 100.00 \\
\hline
\end{tabular}


Peres-Dias QN, Oliveira CD, Souza MB, Meira AM, Villanova CB. Sand fly species composition (Diptera: Psychodidae: Phlebotominae) in the municipality of Cantagalo, an area with sporadic cases of human cutaneous leishmaniasis in Rio de Janeiro State, Brazil. Rev Inst Med Trop Sao Paulo. 2016;58:50.

Among the five most abundant species, three species of epidemiological importance for ACL were found: Nyssomyia intermedia, Nyssomyia whitmani, and Migonemyia migonei. It is worth noting that these three vector species correspond to $70 \%$ of the sand flies that we have collected.

Nyssomyia intermedia is considered a dominant vector of ACL in Brazil $^{8}$. Nyssomyia whitmani has been considered a vector of $L$. $(V$.) braziliensis in the northeastern, southeastern, central, and southern Brazil. In northern Brazil, $N y$. whitmani is also a vector of $L$. (V.) shawi ${ }^{9}$. Several entomologic surveys confirmed $\mathrm{Ny}$. intermedia as the predominant species in peridomestic environments in many municipalities of Rio de Janeiro State, while Ny. whitmani is not very abundant ${ }^{4}$. It is possible to note that the greater the distance from the coastal region of Rio de Janeiro State, the greater the density of $N y$. whitmani, and this probably happens due to the phyto and physio-geographical conditions of each region. In the studied area (Fig. 1-B) as well as in endemic areas for ACL in Rio de Janeiro State (Fig. 1-A), Ny. intermedia was the most abundant species, followed by $N y$. whitmani $i^{10,11,12,13,14,15}$ (Fig. 2-B).

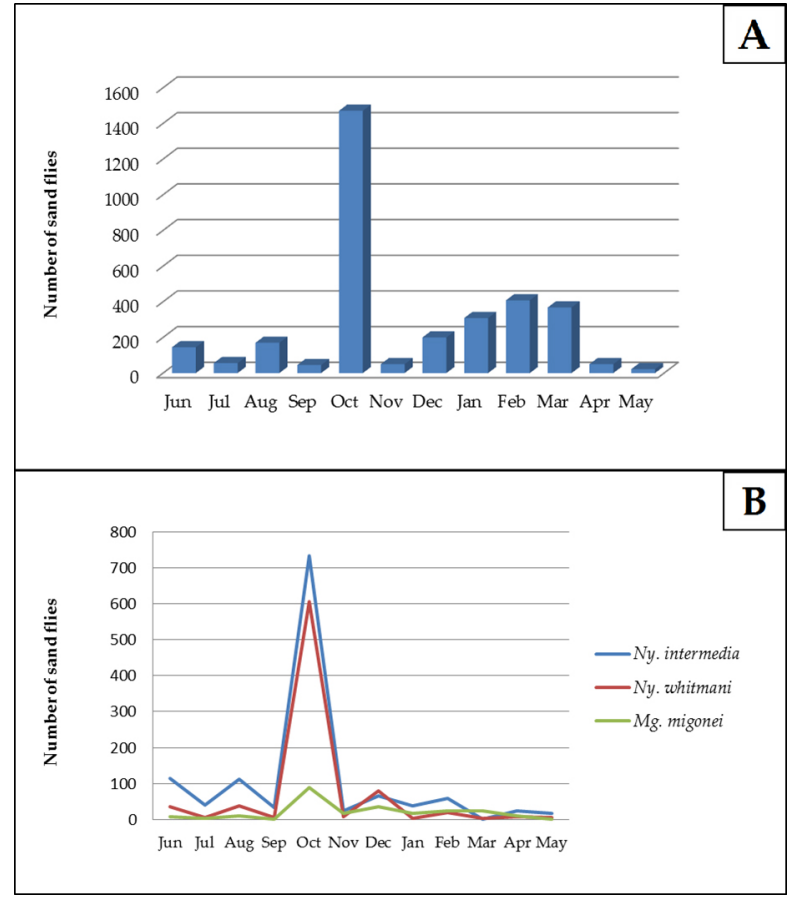

Fig. 2 - Seasonality of the species captured from June 2012 to May 2015 in the municipality of Cantagalo, Rio de Janeiro State.

Migonemyia migonei has been documented as a high potential vector species of $\mathrm{ACL}^{16}$. Pintomyia fischeri is associated to ACL transmission cycles in some Brazilian States ${ }^{17}$. Females belonging to the cortelezzii complex were found to be infected by L. braziliensis in Minas Gerais State $^{18}$.

A limitation of our study was the alternation of traps between the two studied sites (districts). This has biased data from each individual site, nevertheless data are still valuable to describe the phlebotomine sand fly fauna of Cantagalo.
The highest abundance of sand flies was observed between October and March. October was the month with the highest abundance of collected sand flies (Fig. 2-A), one month before the peak in the summer rainfall. October was also the month with the highest abundance of species of epidemiological importance for ACL in this area - Ny. intermedia, $N y$. whitmani and $\mathrm{Mg}$. migonei.

Finally, our collections allowed us to report seven species for the first time in Cantagalo, Rio de Janeiro, Brazil. We also found that dominant vector species were among the most abundant in the community of sand flies that we sampled with a CDC trap. Given the sporadic occurrence of ACL cases in the area, but the sustained transmission of infection, we believe that the monitoring of sand flies in this area could be part of a pro-active surveillance program to better understand, and prevent, the transmission of ACL.

\section{CONFLICT OF INTEREST}

The authors declare that there is no conflict of interest.

\section{ACKNOWLEDGEMENTS}

This study was performed as a cooperation between the Department of Biological Sciences (Oswaldo Cruz. Foundation) and the Secretaria Municipal de Saúde de Cantagalo.

\section{REFERENCES}

1. Brasil. Secretaria de Vigilância em Saúde. Sistema de Informação de Agravos de Notificação (SINAN). [cited 2014 Oct 23]. Available from: http://www.saude.gov. $\mathrm{br} /$ sinanweb

2. Instituto Brasileiro de Geografia e Estatística (IBGE). Rio de Janeiro: Cantagalo [cited 2015 June 17]. Available from: http://www.cidades.ibge.gov.br/xtras/perfil. php?lang=\&codmun $=3301108$.

3. Galati EA. Classificação de Phlebotominae. In: Rangel EF, Lainson R, editores. Flebotomíneos do Brasil. Rio de Janeiro: Fiocruz; 2003. p. 23-51.

4. Carvalho BM, Dias CM, Rangel EF. Phlebotomine sand flies (Diptera, Psychodidae) from Rio de Janeiro State, Brazil: species distribution and potential vectors of leishmaniasis. Rev Bras Entomol. 2014;58:77-87.

5. Calzada JE, Saldaña A, Rigg C, Valderrama A, Romero L, Chaves LF. Changes in phlebotomine sand fly species composition following insecticide thermal fogging in a rural setting of Western Panamá. PLoS One. 2013;8:e53289.

6. Chaves LF, Añez N. Species co-occurrence and feeding behavior in sand fly transmission of American cutaneous leishmaniasis in western Venezuela. Acta Trop. 2004;92:21924.

7. Chaves LF, Añez N. Nestedness patterns of sand fly (Diptera: Psychodidae) species in a neotropical semi-arid environment. Acta Trop. 2016;153:7-13.

8. Marcondes CB. A redescription of Lutzomyia (Nyssomyia) intermedia (Lutz \& Neiva, 1912) and resurrection of L. neivai (Pinto, 1926) (Diptera, Psychodidae, Phlebotominae). Mem Inst Oswaldo Cruz. 1996;91:457-62.

9. da Costa SM, Cechinel M, Bandeira V, Zannuncio JC, Lainson R, Rangel EF. Lutzomyia (Nyssomyia) whitmani s.l. (Antunes \& Coutinho, 1939) (Diptera: Psychodidae: Phlebotominae): geographical distribution and the epidemiology of American cutaneous leishmaniasis in Brazil: mini-review. Mem Inst Oswaldo Cruz. 2007;102:149-53. 
Peres-Dias QN, Oliveira CD, Souza MB, Meira AM, Villanova CB. Sand fly species composition (Diptera: Psychodidae: Phlebotominae) in the municipality of Cantagalo, an area with sporadic cases of human cutaneous leishmaniasis in Rio de Janeiro State, Brazil. Rev Inst Med Trop Sao Paulo. 2016;58:50.

10. de Souza MA, Sabroza PC, Marzochi MC, Coutinho SG, de Souza WJ. Leishmaniose visceral no Rio de Janeiro. 1. Flebotomíneos de área de procedência de caso humano autóctone. Mem Inst Oswaldo Cruz. 1981;76:161-8.

11. Souza MB, Marzochi MC, Carvalho RW, Conceição NF, Ponte CS. Flebotomíneos em áreas de ocorrência de leishmaniose tegumentar no município de São José do Vale do Rio Preto, Rio de Janeiro, Brasil. Parasitol al Dia. 1995;19:97-103.

12. Souza MB, Pujol-Luz JR, Marzochi MC, Carvalho RW, Ponte CS, Meira AM. Estudo da fauna flebotomínica em área de leishmanioses tegumentar americana e visceral, zona peri-urbana do bairro de Jacarepaguá, Rio de Janeiro. Entomol Vectores. 2000;17:36575 .

13. Souza MB, Cardoso PG, Sanavria A, Marzochi MC, Carvalho RW, Ribeiro PC, et al. Fauna flebotomínica do município de Bom Jardim, região serrana do Estado do Rio de Janeiro, Brasil. Rev Bras Parasitol Vet. 2003;12:150-3.

14. Rangel EF, de Souza NA, Wermelinger ED, Barboza AF. Infecção natural de Lutzomyia intermedia (Lutz \& Neiva, 1912) em área endêmica de leishmaniose tegumentar do estado do Rio de Janeiro. Mem Inst Oswaldo Cruz. 1984;79:395-6.

15. Carvalho RW, Serra-Freire NM, Souza MB. Fauna de flebótomos da Ilha do Araújo, município de Paraty-RJ. 1. Diversidades e aspectos do comportamento. Parasitol al Dia. 1995;19:104-12.
16. de Pita-Pereira D, Alves CR, Souza MB, Brazil RP, Bertho AL, Barbosa AF, et al. Identification of naturally infected Lutzomyia intermedia and Lutzomyia migonei with Leishmania (Viannia) braziliensis in Rio de Janeiro (Brazil) revealed by a PCR multiplex non-isotopic hybridisation assay. Trans R Soc Trop Med Hyg. 2005;99:90513.

17. Souza NA, Silva JB, Godoy RE, Souza FJ, Andrade-Coelho CA, Silva VC, et al. Studies on Phlebotominae (Diptera: Psychodidae) in the Campus FIOCRUZ Mata Atlântica, Jacarepaguá, in the city of Rio de Janeiro, Brazil. Rev Soc Bras Med Trop. 2015;48:2632.

18. Saraiva L, Andrade-Filho JD, Silva SO, Andrade AS, Melo MN. The molecular detection of different Leishmania species within sand flies from a cutaneous and visceral leishmaniasis sympatric area in Southeastern Brazil. Mem Inst Oswaldo Cruz. 2010;105:1033-9.

Received: 10 November 2015

Accepted: 22 January 2016 